\title{
ALDH2 Gene
}

National Cancer Institute

\section{Source}

National Cancer Institute. ALDH2 Gene. NCI Thesaurus. Code C84921.

This gene plays a role in intermediary metabolism. 